\title{
COMBINING ABILITY AND GENETIC VARIANCE COMPONENTS OF A DIALLEL CROSSES AMONG RESTORER LINES OF RICE (Oryza sativa, L.). Abd El-Hadi, A. H. ${ }^{1}$; H. F. El-Mowafi ${ }^{2}$ and O. A. El-Badawy ${ }^{2}$ 1- Genetic Dept., Fac. of Agric., Mansoura University,Mansoura, Egypt. 2- Rice Res. and Training Center (RRTC), Sakha, Kafr El-Sheikh, Egypt.
}

\begin{abstract}
Fifteen hybrids were produced from a partial diallel crosses mating design among six lines. They were studied along with their parents for combining ability and genetic variations for yield and its component characters. Both GCA and SCA variances were found to be highly significant for all the characters indicating the importance of both additive and non-additive gene action. However, preponderance of non-additive (dominance) gene action was recorded for grain yield plant ${ }^{-1}$, panicles plant $^{-1}$, filled grains panicle ${ }^{-1}$ and spikelets fertility $\%$ while 1000 -grain weight was controlled by additive type.

The restorer rice genotype , PR78, PR2 and Giza 178R were found to be good combiners for grain yield plant ${ }^{-1}$ and most of yield component characters. The crosses involving the above parents were promising because they showed high SCA effects.
\end{abstract}

\section{INTRODUCTION}

Rice is an important crop in Egypt and its production plays a significant role for local consumption and export. It occupies about 0.7 million hectares of irrigated area which produce about 6.87 million tones of rice. Therefore, hybrid rice with $15.20 \%$ yield heterosis over conventional varieties happens to be one option to enhance and productivity levels, since the area under rice cultivation can not be further increased due to water shortage.

The nature and magnitude of gene action which involved in the expression of quantitative traits are important for successful development of crop varieties. Also the correct choice of parents for hybridization is crucial for the development of new cultivars. Combining ability analysis provides such information needed for effective breeding programmes. This analysis helps in the identification of parents with high general combining ability (GCA) and parental combinations with high specific combining ability (SCA). The estimation of additive and non-additive gene action through this technique may be also useful in determining the possibility of commercial exploitation of heterosis and isolation of new lines from the progenies of the high yielding hybrids. (Yadav and Murty 1966, Yadav et al., 1999 and Yan et al., (2000).

\section{MATERIALS AND METHODS}

A partial diallel crosses was done using six Egyptian restorers for CMS lines of rice. These lines were: Giza 178R, Giza 182 R, GZ 5121 -5-2R, HVR2, PR2 and PR78. All the $15 F_{1} s$ along with theire parents were evaluated in randomized complete blocks design with three replications. Spacing of $20 \mathrm{~cm}$ between rows and $20 \mathrm{~cm}$ between plants were applied during the two summer seasons of 2005 and 2006 at Rice Research and 
Training Center (RRTC),Sakha, Kafr El-Sheikh, Egypt. The recommended cultural practices were followed.

Data were recorded on ten randomly selected plants from each replication and mean values were used for statistical analysis. Combining ability analysis was carried out according to method two and model.1 of Griffing's (1956). Diallel analysis of Hayman's (1954) was used in which the array variance $(\mathrm{Vr})$ and parent array progeny covariance $(\mathrm{Wr})$ for characters were computed. The following genetic components of variation were calculated by using Hayman's procedure (1954) and presented by Sing and Chaudhary (1977).

D = Components of variation due to additive gene effects.

$\mathbf{F}=$ Mean of covariance of additive and dominance effects over the arrays.

H1 = Component of variation due to dominant gene effects.

H2= Dominance indicated asymmetry of positive and negative effects;

Where:

$\mathrm{H} 2=\mathrm{H} 1\left\{1-(\mathrm{U}-\mathrm{V})^{2}\right\}$

$\mathbf{U}=$ Proportion of positive genes in the parents.

$\mathbf{V}=$ Proportion of negative genes in the parents $\{$ or of the genes with positive ( negative ) effects $\}$ and where $\mathbf{U}+\mathbf{V}=\mathbf{1}$

$\mathbf{h}^{2}=$ Dominance effects ( as the algebraic sum over all loci in heterozygous phase in all crosses)

$\mathbf{E}=$ Component of variation due to environmental effects.

The observations were recorded for five quantitative characters. These characters were: grain yield plant ${ }^{-1}$, panicles plant $^{-1}$, filled grains panicle $^{-1}$, 1000-grain weight (g) and spikelets fertility percentage ( \% ).

\section{RESULTS AND DISCUSSION}

Highly signifiant differences were found among genotypes, parents and crosses for all studied yield characters as presented in Table 1. These results indicated a wide range of genetic variations among the parental restorer lines used in this investigation. Parents vs crosses mean squares indicated that the average heterosis was significant in all crosses in the two years and their combined data over years for all yield characters. The interaction of genotypes, parents, crosses and parents vs crosses with the two years were highly significant. It is important to evaluate the potentiality of parents for the expression of heterosis through the evaluation of their performances over a number of environmental conditions. Genetic diversity alone would not guarantee the expression of heterosis but suitability of the environmental conditions is required. Similar results were obtained by Ahmed (2004) and Awad Allah (2006).

Both general and specific combining ability variances were found to be highly significant for all grain yield and its component characters in the two years and their combined data. Except for general combining ability of panicles plant ${ }^{-1}$ in the first year and spikelets fertility \% in the second year as shown in Table 2. These results indicated the importance of both additive and non-additive genetic variances in determining the inheritance of the studied characters. The interactions of years with GCA and SCA were found 
to be highly significant for all yield and its component characters indicating that both additive and non-additive genetic variance tended to interact with the environment. Therefore, selection for these characters would not be effective in a single environment, but more environments would be required. This result is in agreement with conclusions made by Ahmad (2004) and Awad Allah (2006).

Table 1: Mean square estimates of ordinary and combining ability analysis for grain yield plant ${ }^{-1}$ and panicles plant ${ }^{-1}$ in 2005 and 2006 years and their combined data.

\begin{tabular}{|c|c|c|c|c|c|c|c|c|}
\hline \multirow[t]{2}{*}{ S. Of. V } & \multicolumn{2}{|c|}{ d.f } & \multicolumn{3}{|c|}{ Grain yield plant $^{-1}$} & \multicolumn{3}{|c|}{ Panicles plant $^{-1}$} \\
\hline & Single & Comb. & Y1 & Y2 & Comb. & Y1 & Y2 & Comb. \\
\hline Years & 1 & 1 & - & - & $1969^{* *}$ & - & - & $14.34^{*}$ \\
\hline Reps with Years & 2 & 4 & - & - & $3.167^{*}$ & - & - & 2.205 \\
\hline Genotypes & 20 & 20 & $207.6^{* *}$ & $141.1^{* *}$ & $148.1^{* *}$ & $11.39^{* *}$ & $14.21^{* *}$ & $8.592^{* *}$ \\
\hline Parents & 5 & 5 & $56.05^{\star *}$ & $23.33^{\star *}$ & $33.85^{\star *}$ & 9.593 & $7.779^{*}$ & $5.964^{\star *}$ \\
\hline Crosses & 14 & 14 & $99.81^{* *}$ & $47.15^{\star *}$ & $38.52^{* *}$ & $9.647^{* *}$ & $16.04^{\star *}$ & $7.890^{* *}$ \\
\hline P. vs crosses & 1 & 1 & $2474^{\star *}$ & $2044^{\star *}$ & $2254^{\star *}$ & $44.82^{\star *}$ & $20.76^{\star *}$ & $31.56^{\star *}$ \\
\hline Genotypes/ years & & 20 & & & $200.6^{* *}$ & & & $17.01^{* *}$ \\
\hline Parents/ years & & 5 & & & $45.53^{\star *}$ & & & $11.41^{* *}$ \\
\hline Crosses/ years & & 14 & & & $108.4^{* *}$ & & & $17.80^{\star *}$ \\
\hline $\begin{array}{l}\text { P. VS } \\
\text { crosses/ }\end{array}$ & & 1 & & & $2264^{\star \star}$ & & & $34.02^{* *}$ \\
\hline G.C.A & 5 & 5 & $28.29^{* *}$ & $15.54^{* *}$ & $15.93^{* *}$ & 2.103 & $8.021^{* *}$ & $4.225^{\star *}$ \\
\hline S.C.A & 14 & 14 & $82.84^{* *}$ & $57.52^{* *}$ & $60.53^{* *}$ & $4.362^{\star *}$ & $3.643^{* *}$ & $2.410^{* *}$ \\
\hline G.C.A / years & & 5 & & & $27.90^{* *}$ & & & $5.899^{* *}$ \\
\hline S.C.A / years & & 14 & & & $79.83^{\star *}$ & & & $5.595^{\star *}$ \\
\hline Error & 40 & 80 & 3.352 & 2.612 & 1.096 & 3.470 & 2.892 & 1.583 \\
\hline GCA/SCA. ratio & & & 0.042 & 0.032 & 0.032 & 0.037 & 0.329 & 0.245 \\
\hline
\end{tabular}

Table 1 cont.: Mean square estimates of ordinary and combining ability analysis for filled grains panicle ${ }^{-1}$ and 1000 -grain weight in 2005 and 2006 years and their combined data.

\begin{tabular}{|c|c|c|c|c|c|c|c|c|}
\hline \multirow[t]{2}{*}{ s. Of . V } & \multicolumn{2}{|c|}{ d. $f$} & \multicolumn{3}{|c|}{ Filled grains panicle-1 } & \multicolumn{3}{|c|}{1000 -grain weight $(\mathrm{g})$} \\
\hline & Single & Comb. & Y1 & Y2 & Comb. & Y1 & Y2 & Comb. \\
\hline Years & 1 & 1 & - & - & $3088^{* *}$ & - & - & $5.573^{* *}$ \\
\hline Reps with Years & 2 & 4 & - & - & 18.55 & - & - & $0.499^{*}$ \\
\hline Genotypes & 20 & 20 & $2294^{\star *}$ & $1566^{\star *}$ & $1595^{\star *}$ & $18.18^{* *}$ & $19.86^{\star *}$ & $18.14^{\star *}$ \\
\hline Parents & 5 & 5 & $324.1^{* *}$ & $900.1^{* *}$ & $296.3^{\star *}$ & $38.70^{\star *}$ & $38.93^{\star *}$ & $38.71^{* *}$ \\
\hline Crosses & 14 & 14 & $990.9^{* *}$ & $1253^{\star *}$ & $865.4^{\star *}$ & $11.42^{\star *}$ & $11.16^{\star *}$ & $10.30^{* *}$ \\
\hline P. vs crosses & 1 & 1 & $30389 * *$ & $9269^{* *}$ & $18307^{* *}$ & $10.10^{\star *}$ & $46.34^{* *}$ & $25.03^{* *}$ \\
\hline $\begin{array}{l}\text { Genotypes/ } \\
\text { vears }\end{array}$ & & 20 & & & $2265^{\star *}$ & & & $19.90^{* *}$ \\
\hline Parents/ years & & 5 & & & $927.9^{* *}$ & & & $38.92^{\star *}$ \\
\hline Crosses/ years & & 14 & & & $1378^{\star *}$ & & & $12.28^{* *}$ \\
\hline $\begin{array}{l}\text { P. vs } \\
\text { crosses/years }\end{array}$ & & 1 & & & $21351^{* *}$ & & & $31.41^{* *}$ \\
\hline G.C.A & 5 & 5 & $352.9^{* *}$ & $655.2^{* *}$ & $457.4^{\star *}$ & $22.20^{\star *}$ & $21.25^{\star *}$ & $21.50^{* *}$ \\
\hline S.C.A & 14 & 14 & $902.0^{\star *}$ & $477.6^{* *}$ & $556.5^{\star *}$ & $0.679^{* *}$ & $1.746^{\star *}$ & $0.894^{* *}$ \\
\hline G.C.A / years & & 5 & & & $550.7^{* *}$ & & & $21.94^{\star *}$ \\
\hline S.C.A / years & & 14 & & & $823.1^{* *}$ & & & $1.531^{* *}$ \\
\hline Error & 40 & 80 & 15.23 & 16.25 & 10.36 & 0.193 & 0.435 & 0.143 \\
\hline GCA/SCA. ratio & & & 0.048 & 0.172 & 0.103 & 4.502 & 1.647 & 3.170 \\
\hline
\end{tabular}


Table 1 cont.: Mean square estimates of ordinary and combining ability analysis for spikelets fertility \% character in 2005 and 2006

\begin{tabular}{|c|c|c|c|c|c|}
\hline \multirow{2}{*}{ S.Of.V } & \multicolumn{2}{|c|}{ d.f } & \multicolumn{3}{|c|}{ Spikelet fertility \% } \\
\hline & Single & Comb. & Y1 & Y2 & Comb. \\
\hline Years & 1 & 1 & - & - & $68.94^{*}$ \\
\hline Reps with Years & 2 & 4 & - & - & $12.30^{*}$ \\
\hline Genotypes & 20 & 20 & $101.1^{* *}$ & $53.91^{* *}$ & $30.02^{* *}$ \\
\hline Parents & 5 & 5 & $117.6^{* *}$ & $26.20^{\star *}$ & $44.59^{* *}$ \\
\hline Crosses & 14 & 14 & $100.0^{* *}$ & $58.80^{* *}$ & $26.45^{\star \star}$ \\
\hline P. vs crosses & 1 & 1 & $33.97^{*}$ & $124.1^{\star *}$ & 7.235 \\
\hline $\begin{array}{l}\text { Genotypes/ years } \\
\text { Parents/ years }\end{array}$ & & $\begin{array}{c}20 \\
5\end{array}$ & & & $99.21^{* *}$ \\
\hline Crosses/ years & & 14 & & & $132.4^{\star *}$ \\
\hline P. vs crosses/years & & 1 & & & $150.8^{\star *}$ \\
\hline G.C.A & 5 & 5 & $32.17^{\star *}$ & 7.206 & $6.954^{\star *}$ \\
\hline S.C.A & 14 & 14 & $34.21^{* *}$ & $21.56^{\star *}$ & $11.02^{\star *}$ \\
\hline G.C.A / years & & 5 & & & $32.42^{* *}$ \\
\hline S.C.A / years & & 14 & & & $44.75^{\star *}$ \\
\hline Error & 40 & 80 & 6.194 & 9.620 & 3.950 \\
\hline GCA/SCA. ratio & & & 0.117 & 0.027 & 0.073 \\
\hline
\end{tabular}

years and their combined data.

*: Significant at $5 \% \quad{ }^{* *}$ : Significant at $1 \%$

Table 2: Estimation of additive genetic variance $\left(\sigma^{2} A\right)$, dominance genetic variance $\left(\sigma^{2} D\right)$, and heritability in broad and narrow senses (Griffings, 1956) for yield and its component characters.

\begin{tabular}{|c|c|c|c|c|c|c|}
\hline \multirow{2}{*}{ Characters } & \multirow{2}{*}{ Years } & \multirow{2}{*}{$\sigma^{2} A$} & \multirow{2}{*}{$\sigma^{2} D$} & \multirow{2}{*}{$\sigma^{2} E$} & \multicolumn{2}{|c|}{ Heritability } \\
\hline & & & & & $h^{2} b$ & $h^{2} n$ \\
\hline \multirow{3}{*}{ Grain yield plant ${ }^{-1}$} & Y1 & -13.64 & 81.73 & 1.117 & 0.948 & -0.197 \\
\hline & Y2 & -10.49 & 56.65 & 0.871 & 0.981 & -0.223 \\
\hline & Comb. & -11.15 & 60.17 & 0.365 & 0.993 & -0.226 \\
\hline \multirow{3}{*}{ Panicles plant ${ }^{-1}$} & Y1 & -0.565 & 3.206 & 1.157 & 0.695 & -0.149 \\
\hline & Y2 & 1.094 & 2.679 & 0.964 & 0.797 & 0.231 \\
\hline & Comb. & 0.454 & 1.883 & 0.528 & 0.816 & 0.158 \\
\hline \multirow{3}{*}{${\underset{-1}{-1}}^{\text {Filled grains panicle }}$} & Y1 & -137.3 & 896.9 & 5.074 & 0.990 & -0.180 \\
\hline & Y2 & 44.39 & 472.2 & 5.418 & 0.990 & 0.085 \\
\hline & Comb. & -24.77 & 553.1 & 3.451 & 0.990 & -0.050 \\
\hline \multirow{3}{*}{$\begin{array}{l}1000 \text {-grain weight } \\
(\mathrm{g})\end{array}$} & $\mathrm{Y1}$ & 5.380 & 0.615 & 0.064 & 0.989 & 0.888 \\
\hline & Y2 & 4.875 & 1.601 & 0.145 & 0.978 & 0.736 \\
\hline & Comb. & 5.152 & 0.846 & 0.048 & 0.992 & 0.852 \\
\hline \multirow{3}{*}{ Spikelets fertility $\%$} & Y1 & -0.510 & 32.15 & 2.065 & 0.939 & -0.015 \\
\hline & Y2 & -3.589 & 18.35 & 3.207 & 0.822 & -0.200 \\
\hline & Comb. & -1.017 & 9.707 & 1.317 & 0.868 & -0.102 \\
\hline
\end{tabular}

The ratio of $\sigma^{2}$ gca / $\sigma^{2}$ sca was less than unity for all the characters except for 1000-grain weight indicating the preponderance of non-additive genetic variance. This finding suggests the importance of non-additive gene action in the production of hybrid rice. On the other hand, the ratio of $\sigma^{2} \mathrm{gca} /$ $\sigma^{2}$ sca was more than unity for 1000-grain weight indicating the preponderance of additive gene action. Similar results were obtained by Lokaprakash et al., (1991), El-Mowafi (2001), El-Mowafi and Abou-Shousha (2003), Abd El-Hadi and El-Mowafi (2005), El-Mowafi et al., (2005), Pradhan et al., (2006), El-Diasty et al., (2008) and Ahangar et al., (2008). 
Part of investigation aimed to study the magnitude of the genetic variance components $i$. e . additive genetic variance $\left(\sigma^{2} A\right)$ and dominance genetic variance $\left(\sigma^{2} D\right)$ and using these components to compute the heritability estimates in broad and narrow sense for the yield and its component characters according to Griffing (1956).

As shown in Table 3 , high relative estimate of dominance genetic variance were obtained achieved for all yield and its component characters except 1000-grain weight. The relative magnitude of the dominance variance to additive variance was very high . Consequently, such type of fomer variance was very important contributer for yield characters except 1000grain weight. For 1000-grain weight, high estimate of additive component of variance in comparison with the dominance genetic variance was found indicateding that the additive genetic component played the most important role in the inheritance of this character.

Concerning heritability, the results revealed that the estimated values of heritability in broad sense $\left(h^{2} b\right)$ were high for all studied yield and its components. On the other hand, heritability values in narrow sense $\left(h^{2} n\right)$ were relatively high for 1000-grain weight and low for the rest of yield characters. These results also illustrate that a major part of the total phenotypic variance was due to additive genetic variance for 1000-grain weight. Accordingly, it is expected that phenotypic selection for this character would be effective to improve the parental restorer lines.. Similar results were obtained by Ahmed (2004) and El Mowafi et al., (2005) . Grain yield plant ${ }^{-1}$, panicles plant ${ }^{-1}$, filled grains panicle ${ }^{-1}$ and spikelet fertility $\%$ which showed low estimates of heritability in narrow sense $\left(h^{2} n\right)$, suggested that a major part of the total phenotypic variance was due to dominance genetic variance and environmental effects. These findings indicated that the selection for these characters should be done in the later generations to make use of transgressive segregation. These results agree with those of: El-Mowafi (1988) and El-Mowafi (1994).

Table 3 presents the genetic components of five yield characters under investigation according to Hayman (1954). The additive component "D" was insignificant positive for grain yield plant ${ }^{-1}$, panicles plant ${ }^{-1}$ filled grains panicle $^{-1}$ in the first and second years and their combioned data and for spikelet fertility \% in the first and second years. However, the values of dominance components " $\mathrm{H}_{1}$ " and " $\mathrm{H}_{2}$ " were significant for these characters. These results indicated that dominance effects were relatively more important than additive in the inheritance of these characters. The magnitude of "H1" was more than "H2" in all characters, indicating that the most loci, the positive and negative alleles, were in equal proportion. These results agree with those of Singh and Richharia (1980), El-Mowafi (1988), El-Mowafi (1994), El-Refaee (2002) and Awad Allah (2006).

Dominance variance over all heterozygous loci " $\mathrm{h}{ }^{2}$ " was highly significant for all yield and its component characters except spikelets fertility in the first year and in the combined data, indicating that dominance was unidirectional. 
Abd El-Hadi, A. H. et al. 
J. Agric. Sci. Mansoura Univ., 34 (3), March, 2009

3 
Abd El-Hadi, A. H. et al.

3

1534 
The values of " $F$ " were insignificant for all yield characters except for 1000 -grain weight suggesting that dominant and recessive genes were in equal proportion. On the other hand, "F" value was significant for 1000-grain weight, indicating that there was asymmetric gene distribution with an axcess of dominant alleles as compared with recessive ones.

The influence of non additive genetic variance as indicated by the relatively larger values of $\left(\mathrm{H}_{1}\right)$ and $\left(\mathrm{H}_{2}\right)$ than those of $(D)$, suggesting that there is a possibility to break the yield plateau of rice by exploiting the dominance genetic components. This finding was further justified by the ratio $\left(H_{1} / D\right)^{1 / 2}$ which revealed over dominance. El-Mowafi (1994), also found over dominance for same characters under normal and saline conditions. The estimate of $\left(H_{1} / D\right)^{1 / 2}$ was less than unity for 1000 -grain weight, suggesting the presence of partial dominance or additive effect for this character.

The ratio of $\left(\mathrm{H}_{2} / 4 \mathrm{H}_{1}\right)$ was less than 0.25 , indicating that a symmetric distribution of positive and negative alleles is existed in the parents. The ratio of total number of dominant to recessive alleles in the parent $(K D / K R)$ was greater than unity of all characters indicating that the proportion of dominant alleles was greater for these characters .

Data presented in Table 3 show that heritability estimates in broad sense $\left(h^{2} b\right)$ were high for yield and its components, while heritability estimates in narrow sense were relatively low for all characters except 1000grain weight. This further suggests that a major part of the total phenotypic variance for these characters was due to dominance genetic variance and environmental effects. These findings lead to conclude that the selection for such characters must be done in the later generations. In case of 1000-grain weight, the estimates of such parameter was high indicating that a major part of total phenotypic variance was due to additive genetic variance. This result agrees with those obtained by El-Mowafi (1988), El-Mowafi (1994) and ElRefaee (2002).

\section{General combining ability effects (GCA).}

The genotypes, PR 78, PR 2 and Giza 178R were found to be good general combiners for grain yield and yield component characters as presented in Table 4. PR 78 was agood combiner for grain yield plant ${ }^{-1}$ and 1000-grain weight. PR 2 was good combiner for grain yield plant ${ }^{-1}$, filled grains panicle ${ }^{-1}, 1000$-grain weight and spikelets fertility $\%$. HVR2 was best combiner for filled grains panicle ${ }^{-1}$ and 1000-grain weight. However GZ5121$5-2 \mathrm{R}$ was best combiner for spikelet fertility \%. So, these could be used as the base restorer parents to improve yield and its components. The performance of parents per se was an indication of their GCA effects for all the above characters, which was reported earlier by Vanaja et al; (2003). Abd El-Hadi and El-Mowafi (2005), and El-Mowafi et al (2005) similar results. In rice, the behavior of parents is a good indication of the performance of their hybrids as it was reported by Gilbert (1958).

Specific combining ability effects (SCA):

The estimated values of SCA effects for yield and its component characters in the two years and their combined data are presented in Table 5. 
Abd El-Hadi, A. H. et al.

4

1536 
J. Agric. Sci. Mansoura Univ., 34 (3), March, 2009

5 
The results revealed that out of 15 cross combinations, 12 crosses showed significant SCA effects for grain yield plant ${ }^{-1}$. In general , the $F_{1}$ crosses GZ5121R X PR2, GZ5121R X PR78, Giza 178R X Giza 182R, Giza 182R X PR2 , HVR2 X PR78 and Giza 178R X HVR2 showed the best positive SCA effects for grain yield plant ${ }^{-1}$ (Table 5). These crosses also showed good specific combinations for most of studied traits.

\section{REFERENCES}

Abd El-Hadi, A. H., and H.F.El- Mowafi ( 2005). Combining ability analysis of the maintainer and restorer lines for cytoplasmic male sterility (CMS) system of hybrid rice. J.Agric.Res.,83(5A):183-196.

Ahangar, L.; G. A. Ranjbar and M. Nouroozi (2008). Estimation of combining ability for yield and yield components in rice (Oryza sativa, L.) cultivars using diallel cross. Pakistan Journal of Biological Sciences 11(1): 1278-1281.

Ahmed. A. R. M. (2004). Genetical studies on some hybrids of rice. MSc Thesis, Fac. of Agric. Mansoura University, Egypt.

Awad Allah, M.A. ( 2006). Application of genetic engineering tools on rice genome. MSc. Thesis, Fac. Agric., El-Azhar Univ., Egypt.

El-Diasty, Z. M.; H. F. El-Mowafi; M. S. Hamada and R. M. Abdallah (2008). Genetic studies on photo-thermo-sensitive genic male sterility (P/TGMS) and its utilization in rice breeding. J. Agric. Sci. Mansoura Univ., 33(5): 3391-3404

El-Mowafi, H.F. (1988). Breeding studies on some traits of crosses and cultivated and induced rice lines. M.Sc. Thesis, Fac. Agric., Tanta Univ., Kafr El-Sheikh, Egypt.

El-Mowafi, H. F. (2001). Study on heterosis in hybrid rice under Egyptian condition. Egypt. J. Appl. Sci.; 16(2): 52-63.

El-Mowafi, H. F. (1994). Studies on rice breeding. Ph. D. Thesis, Fac. Agric., Kafer El-Shiekh Tanta Univ., Egypt.

El-Mowafi, H.F. and A.A. Abou-Shousha (2003). Combining ability and heterosis analysis of diverse CMS lines in hybrid rice. J. Agric. Res. Tanta Univ., 29(1): 106-127.

El-Mowafi, H.F.; A.O. Bastawisi; M.I. Abou Youssef and F.U. Zaman (2005). Exploitation of rice heterosis under Egyptian conditions. Egypt. J. Agric. Res. 389 (5A): 143-166.

El-Refaee, Y. Z. E. (2002). Genetical and biochemical studies on heterosis and combining ability in rice. M. Sc. Thesis, Fac. Agric., Tanta Univ., Kafr El-Sheikh, Egypt.

Gilbert, N. E. G. (1958). Diallel cross in plant breeding. Heredity 12: 477-498.

Griffing, J. B. (1956). Concept of general and specific combining ability in relation to diallel crossing system. Aust. J. Biol. Sci. 9:43.

Hayman, B. I. (1954). The theory and analysis of diallel crosses. Genetics. 39:789-809. 
Lokaprakash, R.; G. Shivashankar; M. Mahaderappa; B.T. Shankaregowda and R.S. Kulkami (1991). Combining ability for yield and its components in rice. Oryza 28(3): 319-322 (Cited From Rice Abstracts. 1995 Vol. 18, No. 1).

Pradhan,-S-K; Bose,-L-K; Jitendriya-Meher (2006). Studies on gene action and combining ability analysis in basmati rice. Journal-of-CentralEuropean-Agriculture. 7(2): 267-272 .

Singh, R. K. and B. D. Chaudhary (1977). Biometrical methods in quantitative genetic analysis. Kalyani Publishers, Ludhiana, India, pp.300.

Singh, R. S. and A. K. Richharia (1980). Diallel analysis for grain yield and its components in rice. J. Agric. Sci. 50(1) : 1-5.

Vanaja,T; Babu,L.C and Radhakrishnan,V.V(2003) Vytilla 3 - a new cytoplasmic male sterile source of tropical rice (Oryza sativa, L.).IndianJournal-of-Genetics-and-Plant-Breeding. 63(1): 30-32.

Yadav, L. S.; D.M. Maurya; S.P. Giri and S.B. Singh (1999). Combining ability analysis for yield and its components in hybrid rice Oryza, 36:3, 208210.

Yadav, S.P. and B.R. Murty (1966). Heterosis and combining ability of different height categories in broad wheat. Indian J. Genetic 36: 184196.

Yan, S.; S. Wen; Z. L; J. Wan; Y. Tian and C. Liu (2000). Study on the combining ability of indica two-line hybrid rice. J. Huazhong Agri. Univ. 19: 204-208.

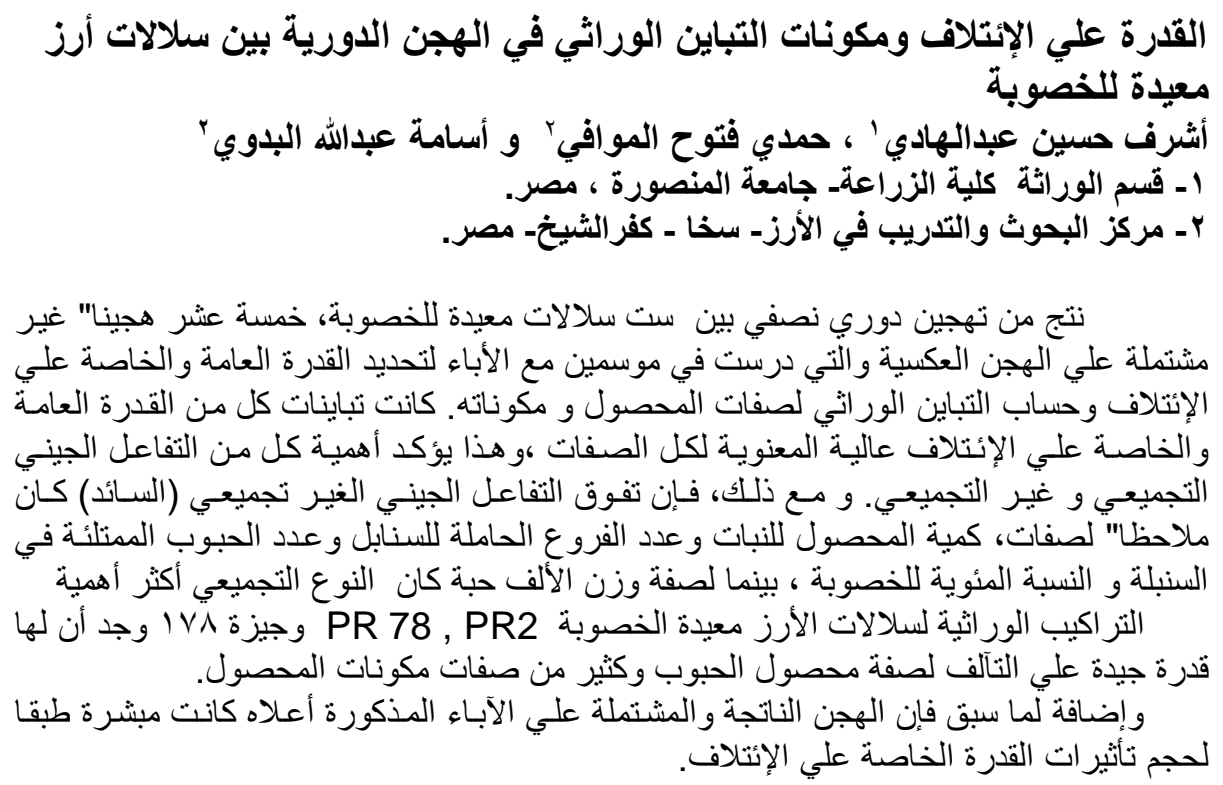


Table 3: Estimates of genetic parameters for grain yield plant ${ }^{-1}$ and panicles plant ${ }^{-1}$ characters in $6 \times 6$ diallel crosses.

\begin{tabular}{|c|c|c|c|c|c|c|}
\hline \multirow{3}{*}{ Genetic parameters } & \multicolumn{6}{|c|}{ Estimates \pm S.E. } \\
\hline & \multicolumn{3}{|c|}{ Grain yield plant $^{-1}$} & \multicolumn{3}{|c|}{ Panicles plant $^{-1}$} \\
\hline & Y1 & Y2 & Comb. & Y1 & Y2 & Comb. \\
\hline Additive effect & $40.910 \pm 18,90$ & $16.630 \pm 15.56$ & $24.990 \pm 17.73$ & $6.039 \pm 2.787$ & $4.900 \pm 4.106$ & $3.931 \pm 1.572$ \\
\hline Dominance effects & & & & & & \\
\hline $\mathrm{H}_{1}$ & $\begin{array}{c}548.30^{* *} \pm \\
47.86\end{array}$ & $\begin{array}{c}349.10^{* *} \pm \\
39.40\end{array}$ & $\begin{array}{c}361.20^{* *} \pm \\
44.91\end{array}$ & $36.59^{* *} \pm 7.058$ & $32.75^{*} \pm 10.40$ & $\begin{array}{c}19.82^{* *} \pm \\
3.981 \\
\end{array}$ \\
\hline $\mathrm{H}_{2}$ & $\begin{array}{c}525.20^{* *} \pm \\
42.86\end{array}$ & $\begin{array}{c}341.40^{\star *} \pm \\
35.28 \\
\end{array}$ & $\begin{array}{c}350.70^{\star *} \pm \\
40.21\end{array}$ & $29.07^{*} \pm 6.321$ & $25.01 \pm 9.311$ & $15.80^{*} \pm 3.565$ \\
\hline$h^{2}$ & $\begin{array}{c}4811.3^{* *} \pm \\
28.23\end{array}$ & $\begin{array}{c}3975.3^{* *} \pm \\
23.73\end{array}$ & $\begin{array}{c}4383.7^{* *} \pm \\
27.05\end{array}$ & $86.50^{\star *} \pm 4.251$ & $\begin{array}{c}39.85^{\star \star} \pm \\
6.262 \\
\end{array}$ & $\begin{array}{c}61.24^{* *} \pm \\
2.398 \\
\end{array}$ \\
\hline Gene distribution & $30.060 \pm 45.68$ & $5.0360 \pm 37.60$ & $17.500 \pm 42.86$ & $11.12 \pm 6.736$ & $0.781 \pm 9.923$ & $2.188 \pm 3.800$ \\
\hline Environmental effects & $1.1250 \pm 7.143$ & $0.8690 \pm 5.880$ & $0.3930 \pm 6.702$ & $1.156 \pm 1.053$ & $0.934 \pm 1.552$ & $0.535 \pm 0.594$ \\
\hline$\left(H_{1} / D\right)^{1 / 2}$ Mean degree of dominance & 3.661 & 4.581 & 3.802 & 2.461 & 2.585 & 2.246 \\
\hline $\begin{array}{l}\mathrm{H}_{2} / \mathbf{4 \mathrm { H } _ { 1 } )} \text { Proportion of genes with } \\
\text { positive } \\
\text { And negative effects on parents. }\end{array}$ & 0.239 & 0.245 & 0.243 & 0.199 & 0.191 & 0.199 \\
\hline $\begin{array}{l}\left(\mathrm{K}_{\mathrm{D}} / \mathrm{K}_{\mathrm{R}}\right) \quad \text { Proportion of dominance } \\
\text { and } \\
\text { Recessive genes in the parents. }\end{array}$ & 1.223 & 1.068 & 1.203 & 2.194 & 1.064 & 1.283 \\
\hline Heritability broad sense. & 0.993 & 0.991 & 0.996 & 0.880 & 0.929 & 0.927 \\
\hline Heritability narrow sense. & 0.114 & 0.100 & 0.093 & 0.127 & 0.452 & 0.391 \\
\hline
\end{tabular}

*: Significant at $5 \%$

**: Significant at $1 \%$

$\left(K_{D} / K_{R}\right)=\left\{(4 D H 1)^{1 / 2}+F\right\} /\left\{(4 D H 1)^{1 / 2}-F\right\}$ 
Table 3 cont.: Estimates of genetic parameters for filled grains panicle ${ }^{-1}$ and 1000 -grain weight characters in $6 \times 6$ diallel crosses

\begin{tabular}{|c|c|c|c|c|c|c|c|}
\hline & \multirow{3}{*}{ Genetic parameters } & \multicolumn{6}{|c|}{ Estimates \pm S.E. } \\
\hline & & \multicolumn{3}{|c|}{ 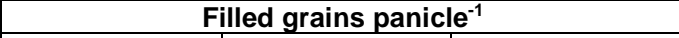 } & \multicolumn{3}{|c|}{1000 -grain weight } \\
\hline & & Y1 & Y2 & Comb. & Y1 & Y2 & Comb. \\
\hline $\begin{array}{l}\text { (D) } \\
\text { (H) }\end{array}$ & $\begin{array}{l}\text { Additive effect } \\
\text { Dominance effects }\end{array}$ & $238.00 \pm 462.0$ & $670.2 \pm 351.7$ & $218.70 \pm 360.8$ & $28.96^{\star \star} \pm 0.489$ & $29.05^{\star \star} \pm 1.034$ & $28.99^{\star \star} \pm 0.329$ \\
\hline $\mathrm{H}_{1}$ & & $5850.9^{* \star} \pm 1169.9$ & $3980.1^{*} \pm 890.7$ & $3709.6^{*} \pm 913.8$ & $5.480^{*} \pm 1.238$ & $12.17^{\star *} \pm 2.618$ & $6.274^{\star *} \pm 0.834$ \\
\hline $\mathrm{H}_{2}$ & & $5296.6^{* *} \pm 1047.7$ & $3046.4^{*} \pm 797.6$ & $3239.9^{*} \pm 818.3$ & $4.740^{*} \pm 1.109$ & $10.86^{* *} \pm 2.345$ & $5.423^{\star *} \pm 0.746$ \\
\hline$h^{2}$ & & $59088^{* *} \pm 704.6$ & $18020^{* *} \pm 536.4$ & $35594^{* \star} \pm 550.4$ & $19.60^{\star *} \pm 0.746$ & $90.03^{\star \star} \pm 1.577$ & $48.44^{* \star} \pm 0.502$ \\
\hline (F) & Gene distribution & $206.30 \pm 1116.6$ & $613.8 \pm 850.1$ & $-40.460 \pm 872.1$ & $5.902^{* *} \pm 1.181$ & $7.926^{*} \pm 2.499$ & $7.062^{\star \star} \pm 0.796$ \\
\hline $\begin{array}{l}(E) \\
\left(H_{1} / D\right)^{1 / 2}\end{array}$ & $\begin{array}{l}\text { Environmental effects } \\
\text { Mean degree of dominance }\end{array}$ & $\begin{array}{c}5.0330 \pm 174.6 \\
4.958\end{array}$ & $\begin{array}{c}5.555 \pm 132.9 \\
2.437\end{array}$ & $\begin{array}{c}3.5640 \pm 136.4 \\
4.118\end{array}$ & $\begin{array}{c}0.068 \pm 0.185 \\
0.435\end{array}$ & $\begin{array}{c}0.147 \pm 0.391 \\
0.647\end{array}$ & $\begin{array}{c}0.051 \pm 0.124 \\
0.465\end{array}$ \\
\hline$\left(\mathrm{H}_{2} / \mathbf{4} \mathbf{H}_{1}\right)$ & $\begin{array}{l}\text { Proportion of genes with positive } \\
\text { and negative effects on parents. }\end{array}$ & 0.226 & 0.191 & 0.218 & 0.126 & 0.223 & 0.216 \\
\hline$\left(\mathrm{K}_{\mathrm{D}} / \mathrm{K}_{\mathrm{R}}\right)$ & $\begin{array}{l}\text { Proportion of dominance and } \\
\text { recessive genes in the parents. }\end{array}$ & 1.192 & 1.463 & 0.956 & 1.612 & 1.534 & 1.709 \\
\hline $\begin{array}{l}\left(h_{\text {bs }}\right) \\
\text { (h ns) }\end{array}$ & $\begin{array}{l}\text { Heritability broad sense. } \\
\text { Heritability narrow sense. }\end{array}$ & $\begin{array}{l}0.997 \\
0.181\end{array}$ & $\begin{array}{l}0.996 \\
0.392 \\
\end{array}$ & $\begin{array}{l}0.997 \\
0.309\end{array}$ & $\begin{array}{l}0.995 \\
0.905\end{array}$ & $\begin{array}{l}0.990 \\
0.797\end{array}$ & $\begin{array}{l}0.996 \\
0.890\end{array}$ \\
\hline
\end{tabular}


Table 3 cont.: Estimates of genetic parameters for spikelet fertility $\%$ character in $6 \times 6$ diallel crosses

\begin{tabular}{|c|c|c|c|c|}
\hline \multirow{3}{*}{\multicolumn{2}{|c|}{ Genetic parameter }} & \multirow{2}{*}{\multicolumn{3}{|c|}{$\begin{array}{l}\text { Estimates } \pm \text { S.E. } \\
\text { Spikelets fertility } \%\end{array}$}} \\
\hline & & & & \\
\hline & & Y1 & Y2 & Comb. \\
\hline (D) & Additive effect & $86.06 \pm 45.29$ & $16.40 \pm 14.52$ & $32.10^{*} \pm 9.737$ \\
\hline (H) & Dominance effects & & & \\
\hline$H_{1}^{\prime}$ & & $346.8^{*} \pm 114.7$ & $185.2^{\star \star} \pm 36.78$ & $111.1^{*} \pm 24.66$ \\
\hline $\mathrm{H}_{2}$ & & $253.3 \pm 102.7$ & $167.0^{\star \star} \pm 32.93$ & $79.89^{*} \pm 22.08$ \\
\hline$h^{2}$ & & $64.85 \pm 69.08$ & $239.5^{\star \star} \pm 22.15$ & $12.97 \pm 14.85$ \\
\hline (F) & Gene distribution & $137.7 \pm 109.5$ & $26.29 \pm 35.10$ & $56.46 \pm 23.53$ \\
\hline (E) & Environmental effects & $2.154 \pm 17.12$ & $3.254 \pm 5.489$ & $1.335 \pm 3.680$ \\
\hline$\left(H_{1} / D\right)^{1 / 2}$ & Mean degree of dominance & 2.007 & 3.361 & 1.861 \\
\hline$\left(\mathbf{H}_{2} / \mathbf{4} \mathbf{H}_{1}\right)$ & $\begin{array}{l}\text { Proportion of genes with positive } \\
\text { and negative effects on parents. }\end{array}$ & 0.183 & 0.226 & 0.180 \\
\hline$\left(\mathrm{K}_{\mathrm{D}} / \mathrm{K}_{\mathrm{R}}\right)$ & $\begin{array}{l}\text { Proportion of dominance and } \\
\text { recessive genes in the parents. }\end{array}$ & 2.325 & 1.626 & 2.793 \\
\hline $\begin{array}{l}\left(h_{\text {bs }}\right) \\
\left(h_{\text {ns }}\right)\end{array}$ & $\begin{array}{l}\text { Heritability broad sense. } \\
\text { Heritability narrow sense. }\end{array}$ & $\begin{array}{l}0.975 \\
0.242\end{array}$ & $\begin{array}{l}0.934 \\
0.084\end{array}$ & $\begin{array}{l}0.946 \\
0.139\end{array}$ \\
\hline
\end{tabular}


Table 4: Estimates of GCA effects for all studied characters.

\begin{tabular}{|c|c|c|c|c|c|c|c|c|c|c|c|c|c|c|c|}
\hline \multirow{3}{*}{ Parents } & \multicolumn{15}{|c|}{ G.C.A effects } \\
\hline & \multicolumn{3}{|c|}{ Grain yield plant $^{-1}$} & \multicolumn{3}{|c|}{ Panicles plant $^{-1}$} & \multicolumn{3}{|c|}{ Filled grains panicle ${ }^{-1}$} & \multicolumn{3}{|c|}{ 1000-grain weight (g) } & \multicolumn{3}{|c|}{ Spikelets fertility \% } \\
\hline & $\cdots$ & Y2 & Comb. & 11 & Y2 & Comb. & Y1 & Y2 & Comb. & Y1 & Y2 & Comb. & Y1 & Y2 & Comb. \\
\hline Giza 178R & $\mid-1.44$ & 1.18 & -0.13 & 0.72 & 1.09 & 0.90 & 5.07 & 3.81 & & $.86^{* \star}$ & $2.62^{* \star}$ & $-2.74^{\star *}$ & -0.49 & -1.55 & -1.02 \\
\hline Giza 182R & -1.63 & -0.88 & -1.26 & -0.13 & -0.49 & -0.31 & $-12.98^{* *}$ & $-14.61^{* *}$ & $-13.80^{* \star}$ & -0.02 & -0.46 & -0.24 & 1.44 & -0.05 & 0.70 \\
\hline GZ5121-5-2R & -0.60 & -1.71 & -1.15 & 0.42 & 1.46 & 0.94 & -0.25 & -6.09 & -3.17 & -0.71 & -0.82 & $-0.76^{*}$ & 1.66 & 0.54 & 1.10 \\
\hline HVR2 & -0.74 & -1.09 & -0.91 & -0.65 & -0.56 & -0.61 & 4.20 & $8.40^{*}$ & $6.30^{*}$ & $1.90^{\star \star}$ & $1.85^{\star *}$ & $1.87^{* *}$ & -3.65 & 1.30 & -1.18 \\
\hline PR2 & 1.11 & 1.65 & 1.38 & -0.42 & -0.80 & -0.61 & 1.31 & $8.59^{*}$ & 4.95 & 0.59 & $1.11^{*}$ & $0.85^{* *}$ & 1.28 & -0.35 & 0.46 \\
\hline PR78 & 3.298 & 0.86 & $2.07^{\star}$ & 0.07 & -0.70 & -0.32 & 2.65 & -0.09 & 1.28 & $1.11^{\star \star}$ & 0.94 & $1.02^{* *}$ & -0.24 & 0.11 & -0.06 \\
\hline LSD 0.05 & 2.99 & 2.64 & 1.71 & 3.04 & 2.78 & 2.05 & 6.37 & 6.58 & 5.25 & 0.72 & 1.08 & 0.62 & 4.06 & 5.06 & 3.25 \\
\hline 0.01 & 3.98 & 3.51 & 2.27 & 4.05 & 3.69 & 2.73 & 8.47 & 8.76 & 6.99 & 0.95 & 1.43 & 0.82 & 5.41 & 6.74 & 4.32 \\
\hline
\end{tabular}

*, ${ }^{* *}$ significant at 0.05 and 0.01 levels, respectively. 
Abd El-Hadi, A. H. et al.

Table 5: Estimates of SCA effects for all studied characters.

\begin{tabular}{|c|c|c|c|c|c|c|c|c|c|c|c|c|c|c|c|c|}
\hline \multirow{3}{*}{\multicolumn{2}{|c|}{ Parent }} & \multicolumn{15}{|c|}{ SCA effects } \\
\hline & & \multicolumn{3}{|c|}{ Grain yield plant $^{-1}$} & \multicolumn{3}{|c|}{ Panicles plant $^{-1}$} & \multicolumn{3}{|c|}{${\text { Filled grains panicle }{ }^{-1}}$} & \multicolumn{3}{|c|}{ 1000-grain weight $(\mathrm{g})$} & \multicolumn{3}{|c|}{ Spikelets fertility \% } \\
\hline & & $\begin{array}{l}1 \\
\end{array}$ & Y2 & Comb. & Y1 & Y2 & Comb. & Y1 & Y2 & Comb. & Y1 & $\overline{Y 2}$ & Comb. & & Y2 & Comb. \\
\hline \multicolumn{2}{|c|}{ Giza 178R X Giza 182R } & $12.67^{\star}$ & 1.97 & $7.32^{\star *}$ & 2.93 & 0.15 & 1.54 & 1.58 & 0.35 & 0.97 & -0.14 & 0.68 & 0.27 & -3.64 & 3.66 & 0.01 \\
\hline & $X$ GZ 5121-5-2R & $-3.70^{*}$ & $2.79^{*}$ & -0.45 & 0.18 & $3.73^{* \star}$ & 1.96 & $27.57^{\star \star}$ & $-13.17^{\star \star}$ & $7.20^{\star \star}$ & $1.28^{\star \star}$ & 0.30 & $0.79^{*}$ & 2.20 & $-9.29^{\star \star}$ & $-3.54^{*}$ \\
\hline & X HVR2 & $6.47^{* \star}$ & $2.86^{*}$ & $4.67^{\star *}$ & -0.25 & 0.89 & 0.32 & $27.49^{* *}$ & $12.05^{\star *}$ & $19.77^{\star *}$ & 0.35 & 0.11 & 0.23 & $8.31^{* *}$ & $-5.33^{*}$ & 1.49 \\
\hline & X PR2 & $-3.74^{\star}$ & 1.54 & -1.10 & -0.20 & -1.10 & -0.65 & $15.67^{* *}$ & $17.15^{* *}$ & $16.41^{*}$ & 0.23 & $1.50^{\star *}$ & $0.86^{\star *}$ & $4.10^{*}$ & 2.94 & $3.52^{*}$ \\
\hline & X PR 78 & -0.10 & $6.99^{\star \star}$ & $3.45^{\star \star}$ & 1.47 & 1.19 & 1.33 & $16.20^{\star *}$ & $-16.08^{\star *}$ & 0.06 & 0.50 & $2.17^{\star \star}$ & $1.33^{* \star}$ & $7.33^{\star *}$ & 0.34 & $3.83^{*}$ \\
\hline \multicolumn{2}{|c|}{ Giza 182R X GZ 5121-5-2R } & $4.53^{\star \star}$ & $5.30^{\star \star}$ & $4.92^{\star \star}$ & 1.19 & 0.81 & 1.00 & 5.50 & $18.40^{* *}$ & $11.95^{\star *}$ & 0.06 & -0.77 & -0.36 & 0.02 & 2.72 & 1.37 \\
\hline & X HVR2 & $-4.36^{*}$ & $3.53^{\star \star}$ & -0.42 & 2.04 & -2.20 & -0.08 & 6.31 & 2.42 & 4.37 & $0.95^{\star *}$ & 0.76 & $0.85^{\star \star}$ & -2.63 & -2.19 & -2.41 \\
\hline & X PR2 & $7.46^{* \star}$ & $6.38^{* *}$ & $6.92^{* *}$ & 0.32 & 0.62 & 0.47 & $26.44^{* *}$ & $-6.86^{*}$ & $9.79^{* *}$ & 0.45 & 0.77 & 0.61 & 2.86 & $-5.43^{*}$ & -1.29 \\
\hline & X PR78 & 2.33 & -0.33 & 1.00 & 0.49 & -0.67 & -0.09 & 5.38 & -0.65 & 2.37 & 0.24 & 0.71 & 0.48 & 1.42 & $-7.23^{\star \star}$ & -2.90 \\
\hline \multicolumn{2}{|c|}{ GZ 5121-5-2R X HVR2 } & $8.15^{\star \star}$ & $-3.17^{*}$ & $2.49^{* *}$ & -1.75 & 1.28 & -0.23 & $-11.03^{* *}$ & $12.90^{* *}$ & 0.93 & -0.56 & 0.40 & -0.08 & $-7.54^{\star *}$ & -3.55 & $-5.54^{* \star}$ \\
\hline & X PR2 & $10.52^{*}$ & $6.98^{\star \star}$ & $8.75^{\star \star}$ & 0.20 & -2.24 & -1.02 & $8.83^{\star \star}$ & $12.55^{\star \star}$ & $10.69^{\star *}$ & 0.20 & $1.62^{\star *}$ & $0.91^{* *}$ & $-4.60^{*}$ & 0.86 & -1.87 \\
\hline & X PR78 & $6.91^{* \star}$ & $8.49^{\star \star}$ & $7.70^{\star \star}$ & 0.90 & -0.24 & 0.33 & $9.46^{\star \star}$ & $15.47^{* *}$ & $12.47^{\star *}$ & -0.21 & -0.08 & -0.14 & 1.72 & 2.79 & 2.26 \\
\hline \multirow[t]{2}{*}{ HVR2 } & X PR2 & 1.50 & $8.47^{* \star}$ & $4.99^{* *}$ & 2.93 & 0.98 & 1.96 & $38.93^{* *}$ & $23.57^{* *}$ & $31.25^{\star \star}$ & $-1.22^{\star *}$ & -0.03 & $-0.63^{*}$ & $6.77^{\star \star}$ & 1.05 & $3.91^{*}$ \\
\hline & X PR78 & $7.32^{* \star}$ & $3.13^{*}$ & $5.22^{* *}$ & 1.24 & 2.75 & 2.00 & $31.09^{* *}$ & $37.45^{\star *}$ & $34.27^{* *}$ & 0.48 & 0.63 & 0.55 & $-9.22^{\star *}$ & 3.42 & -2.90 \\
\hline PR2 & X PR78 & $3.49^{*}$ & -0.87 & 1.31 & $-3.69^{*}$ & -0.51 & $-2.10^{\star}$ & -1.06 & -0.50 & -0.78 & $1.19^{\star \star}$ & -0.63 & 0.28 & -0.11 & 1.93 & 0.91 \\
\hline \multicolumn{2}{|c|}{\begin{tabular}{|r|} 
LSD 0.05 \\
0.01
\end{tabular}} & $\begin{array}{l}2.99 \\
3.98\end{array}$ & $\begin{array}{l}2.64 \\
3.51\end{array}$ & $\begin{array}{l}1.71 \\
2.27\end{array}$ & $\begin{array}{l}3.04 \\
4.05\end{array}$ & $\begin{array}{l}2.78 \\
3.69\end{array}$ & $\begin{array}{l}2.05 \\
2.73\end{array}$ & $\begin{array}{l}6.37 \\
8.47\end{array}$ & $\begin{array}{l}6.58 \\
8.76\end{array}$ & $\begin{array}{l}5.25 \\
6.99\end{array}$ & $\begin{array}{l}0.72 \\
0.95\end{array}$ & $\begin{array}{l}1.08 \\
1.43\end{array}$ & $\begin{array}{l}0.62 \\
0.82\end{array}$ & $\begin{array}{l}4.06 \\
5.41\end{array}$ & $\begin{array}{l}5.06 \\
6.74\end{array}$ & $\begin{array}{l}3.25 \\
4.32\end{array}$ \\
\hline
\end{tabular}

${ }^{*},{ }^{* *}$ significant at $\mathbf{0 . 0 5}$ and 0.01 levels, respectively. 